\title{
Speculation, Transportation, and Tobacco
}

Mr. Joseph P. DAy of New York has again added to the collection of the Society, this time with an interesting assortment of three English books from the eighteenth century, and a fourth relating to the canal-building fever with which American cities were taken early in the nineteenth. The first item consists of two volumes of quotations on the London Stock Exchange, in 1725 and 1737. The earlier one is published by "John Castaing, Broker, at his Office at the Stationers, next the General-Post-Office in Lombard-Street"; the second by his widowed sister and another broker, Richard Shergold.

John Houghton, apothecary, fellow of the Royal Society, and editor of a financial paper which gave a weekly history of commercial and financial speculation, had kept a weekly register of several important stocks from 1694 to 1703 . Another, more extensive list was published twice a week by one John Freke, broker, from I 7 I 4 . These of Castaing's were likewise published twice a week, and would be "Deliver'd at 35 . per Quarter as far as Temple-bar."

The Stock Exchange as an institution came into being with the beginning of speculation, in the reign of William and Mary. There had been commercial brokers since the fourteenth century, but stockbrokers proper did not appear until, at the end of the seventeenth, the accumulation of surplus savings had created a demand for channels of investment. These brokers and their clients had their first quarters in the Royal Exchange. The building was shared with the merchants, much to the annoyance of the latter. Indeed, they poured such a stream of complaints and abuse upon the poor stockbrokers that the latter were finally driven into Exchange Alley, the nearness of which to the financial centre, and the convenient coffee-houses it offered, made it their logical refuge. The Alley was the home of the Stock Exchange at the time of these lists.

They begin with the "course of exchange" on foreign cities, and include also the prices of certain staple commodities, like "coals" in Freke's lists, and "Colchester Crown Bays" (a fine variety of woollen cloth) in Castaing's. Lottery tickets, a very common investment at the time, are also quoted.

Government loans were common enough in the days of the Stuarts, but William III, by funding the national debt, made the 
first systematic attempt to provide for repaying them. Under his régime, and those of later monarchs, government securities, some of which are listed, began to bear some resemblance to modern government bonds.

The stocks included were largely those of banks, like the Million Bank, and of the great trading companies, like the East India, South Sea and African. These latter were not joint stock corporations in the modern sense. Their only feature which improved on the earlier "ventures," when a number of individuals each subscribed what amount he pleased for a particular voyage, and received profits accordingly, was an arrangement by which members of the company who wished could subscribe a given amount of money to be used for any one of a number of voyages, at the discretion of the directors.

One of the trading companies listed is the notorious South Sea Company. In the years covered by the lists, its stock was reduced to a sound basis, and selling for a conservative IOI or IO2. Five years earlier, the stock was soaring from 770 to 1000 , I 100 and I 200 , while "the people of the country, from the Cabinet Minister, nay from Royalty itself, to the veriest vagabond, were frantic in the distraction of the gamble; the tatterdemalion fraternity vied with ladies of rank in making a pandemonium of Change Alley; and the Bank of England itself was freely accused of involving itself in the scandal." 1

The company had been formed for the purpose of developing trade with South America. The right of importing Negroes into Spanish America, under certain regulations was granted it under the Treaty of Utrecht. Later, it proposed to absorb the national debt, by purchase or subscription. The high price offered, government favor and such rumors as that to the effect that Peru was to come under the protection of the English Government, combined to induce a fever of speculation that ended in a collapse involving peer, poet, divine and even the Chancellor of the Exchequer himself.

A list of "ye bubbles" which came to the same end as did the South Sea speculation, includes "Bleaching of Hair, Colchester Bays, Fitting Ships against Pyrates, Transmutation of Quick Silver, Insurance of Marriages from Divorce, and Air Pump for the Brain."

I Charles Duguid, "The Story of the Stock Exchange." 
Between the years of the two Stock Exchange lists, comes a bill introduced by Walpole in 1733 , for the regulation of the customs on tobacco. It proposed to enforce the storing of all tobacco in closely supervised government warehouses, from which that for domestic consumption could not be taken without the payment of a specified duty. Merchants intending to reëxport tobacco were to furnish sufficient security, which would be discharged upon the presentation of a certificate from the appropriate customs officials that the goods had been unloaded there all in good order.

The act was expected to stop the smuggling which had been going on at a lively pace since the first two Stuarts, in spite of their loathing for the weed on moral grounds, found it to their interest to support the young colonies of Virginia and Maryland by fostering the trade, and at the same time to utilize an added source of revenue by making it a royal monopoly. England would have its tobacco. High duties discouraged the American planters, so tobacco began to be grown in England. In spite of the fact that it was prohibited, in order to protect Colonial trade, British farmers continued to plant, defend their crops with violence, or even insurrections, and make a handsome profit, until the end of the seventeenth century.

With this problem disposed of, that of smuggling remained. Walpole's bill bade fair to put an end to this, but was defeated the first time it was introduced on account of its provision for a small excise duty, a thing abhorred by all true Englishmen. Substantially the same act was later put through by Pitt.

The American item is a survey for the route to be followed by the Chesapeake and Ohio Canal. It recalls the canal mania which swept the country before the introduction of the railroad. The Erie was the first of these great artificial waterways built with the idea of attracting western trade, and others soon followed. Baltimore's reply to New York was first couched in terms of the projected Chesapeake and Ohio Canal. The final answer, however, came in the form of the Baltimore and Ohio Railroad. The contest between canal and railroad could have had but one ending, and the victory of the Baltimore and Ohio definitely decided the issue, giving the railroad supremacy in the field of transportation.

The Stock Exchange has grown into a major institution in the business world; England has become a free trade country, and the railroad has superseded the canal; but each of these items is a detail in one of the great phases of the building of modern business. 